seem to have a fair share allotted to them, and the same is also the case in the courses for the senior scholarships and honours-which latter cannot be competed for until the end of one year after the candidate takes his B.A. degree. A Bacluclor of Arts obtaining honours can have his M.A. degree without special examination; all others have to pass an M.A. cxamination.

It is probable that for some time to come there will be great differences of opinion as to how the natural sciences should be taught and examined in in our universities. Some incline to limit the courses in botany and zoology, and to require a good sound knowledge of the prescribed work; others imagine that the effect of limiting a course is to produce a specialist, which, they argue, is to spoil a student; but the mean appears to us to be not so hard to find. A sound general knowledge of development and of physiology might certainly be demanded of all students, and the field of biology being too large for any human being to work over, the student might, as to details of structure, \&c., be limited to the study of some defined class. It is in this direction evidently that Prof. Hutton has framed the schedulc of zoology and botany, a schedule which, while we acknowledge it to be excellent from a general point of view, is, we are firmly persuaded, longer and more profound than is expedient in a new country, where the teaching power is not great. We are fully aware that there is a tendency in classical and mathematical teachers to believe that the study of natural science is something quite easy; but those able to judge have long agreed that not only does this study call for all the best talents, but that the student too often approaches it long after the impressionable periad of his life : a little Latin, perhaps less Greek, a schoolboy knows ; arithmetic, algebra, and geometry he is fairly familiar with; but the natural sciences and the how he lives, moves, and has his being, of these he is fain to exclaim, But who are ye? The professors of natural science must bide their time; it is no doubt coming, for biology is now somewhat taught in our schools, and may be will be taught on the mother's knee; but in the meanwhile let them not exact too musch from candidates for B.A. degrces or honours ; let them progress surely, even though they be accused of progressing slowly. $\Lambda$ s to the New Zealand University, we shall follow its progress with pleasure, and trust it may soon fulfil the great expectations that we have of it.

\section{DOCTORED WINES}

$\mathrm{T}^{\mathrm{H}}$ E French Government have just passed a most salutary measure, which will have for effect the diminution, if not the complete suppression, of the process known as plistrage, now become an almost constant custom through most of the wine districts of France, and which, from having at first been performed on a very moderate scale, has lately enormously increased, till it has developed into a crying abuse. The plâtrage is carried on during the fermentation, and consists in merely sprinkling the grapes, as successive baskets of them are emptied into the fermentation vats, with plaster of Paris -calcium sulphate-(French platre), mincralogically known as gypsum, or sclenite, in fine powder. Now the grape-juice contains sevcral salts of potash, among which the most abundant are the tarirate and bi-tartrate, and these decompose when placed in contact with the calcium sulphate, forming calcium tartrate-an insoluble salt-and potassium sulphate.

In the case of potassium bi-tartrate, potassium bi-sulphate is formed. Now besides the salts of potash above named, the juice of the grape contains grape-sugar, a nitrogenous fermenting principle and an astringent principle-to which latter new red wines owe much of their harshness-- and also a red colouring-matter, with which the astringent principle is intimately associated. The fermentation splits up the grape-sugar, as it is well known, into carbonic acid, which escapes with effervescence, and alcohol, which remains dissolved. In pure undoctored wines, in proportion to the development of alcoholic strength, and as the wine by age tends to become more acid, potassium bi-tartrate separates as a crystalline precipitate, forming the chief constituent of the deposit in the casks known as lees, or, when it forms in bottled wines, as the crust.

Now the astringent principle which in the red grape is, as we have explained, intimately combined with the colouring-matter, seems to be held more or less in solution by the tartrates, and as these subside with age the wine grows less barsh, losing at the same time much of its colour, and is said to ripen or grow mellow. As the astringent principle however disappears, the wine, if it be one of the wcaker French wines, tends to run to the acetous fermentation, and this is why we frequently find a wine become sour and unpalatable shortly after it has mellowed with age and arrived at its maximum of perfection. Many a bin of valuable claret or Burgundy has thus suddenly surprised and disappointed its possessor, changing in the short space of a few months from fine mellow wine to undrinkable vinegar.

Now, as stated above, calcium sulphate (platre) decomposes the potassium tartrates, and by withdrawing them and substituting the potassium sulphate, tends to prevent much of the colouring and astringent matter from passing into solution, so that this so-called platrage is nothing more than a means employed by the Bordelais and Burgundians for giving to their wines a fictitious effect of age, and they naturally defend a practice which cnables them to bring their wines sooner into the market, economising their outlay in casks, and diminishing the chances of loss entailed by keeping a large stock of wine on hand. Further the process lends itself to fraud, permitting the wine merchants of Bordeaux and Burgundy to import the strong harsh wines of the north of Spain and the south-east of France, which, when blended with the small, poorer wines of the hill-districts of their own country, and then being platrés (that is agitated with powdered calcium sulphate), become mild and palatable. Thousands of hogsheads of wines thus blended and doctored are annually sold, and too often at the high rates commanded by pure vintage wines. Under the provisions of the new act no wine is allowed to be brou: tht into commerce if it contains over two grammes of potassium sulphate per litrc. Fven this proportion is too large, plâtragc should bc entircly prohibited; but when we consider that wines are now often sold with five or six grammes of this salt to the litte, it was time indecd that some measures should be taken. The merchants defend themselves on the basis of the practice being innocuous, and that while it promotes the keeping qualitics of the winc, even four grammes of potassium sulphate could do no harm. It is the greatest possible mistake to fancy that platrage makes wine keep; for, no the contrary, it withdraws from it the astringent principle, a most potent means of its preservation. For a Bordeaux merchant to contend that forty grains of potassium sulphate to the pint of wine is not or cannot be unwholesome, is a thesis which may be agrecable to his pocket, but certainly ought to be discouraged, for, to say the least, it would surely be prejudicial to the stomachs of delicate or dyspeptic consumers. Not very many years since a case occurred of actual death by poisoning from the administration of a comparatively small dose of potassium sulphate, and this salt is well known in medicine as a drastic and dangerous purgative. We should then be most sincerely grateful to the French Minister of Commerce for the prudent forethought with which be has protected the consumers of French wines from a practice which bad grown into a crying abuse, and for giving us onc more guarantee for the purity of these wines, justly ranked as the most estcemed that the world produces. 